\title{
Enhanced mitochondrial metabolism may account for the adaptation to insulin resistance in islets from C57BL/6J mice fed a high-fat diet
}

\author{
M. Fex • M. Dekker Nitert • N. Wierup • F. Sundler • \\ C. Ling $\cdot$ H. Mulder
}

Received: 27 May 2006 / Accepted: 9 August 2006 / Published online: 9 November 2006

(C) Springer-Verlag 2006

\begin{abstract}
Aim/hypothesis Hyperinsulinaemia maintains euglycaemia in insulin-resistant states. The precise cellular mechanisms by which the beta cells adapt are still unresolved. A peripherally derived cue, such as increased circulating fatty acids, may instruct the beta cell to initiate an adaptive programme to maintain glucose homeostasis. When this fails, type 2 diabetes ensues. Because mitochondria play a key role in beta cell pathophysiology, we tested the hypothesis that mitochondrial metabolism is critical for beta cell adaptation to insulin resistance.

Methods C57BL/6J mice were given high-fat (HF) diet for 12 weeks. We then analysed islet hormone secretion, metabolism in vivo and in vitro, and beta cell morphology.
\end{abstract}

Electronic supplementary material Supplementary material is available in the online version of this article at http://dx.doi.org/ $10.1007 / \mathrm{s} 00125-006-0464-4$ and is accessible to authorised users.

M. Fex $\cdot$ M. D. Nitert $\cdot$ N. Wierup $\cdot$ F. Sundler $\cdot$ H. Mulder

Department of Experimental Medical Science,

Division of Diabetes, Metabolism, and Endocrinology,

Lund University,

Lund, Sweden

M. Fex $\cdot$ M. D. Nitert $\cdot$ N. Wierup $\cdot$ F. Sundler $\cdot$ C. Ling $\cdot$

H. Mulder

The Diabetes Programme at Lund University,

Lund, Sweden

C. Ling

Department of Clinical Sciences, Malmö University Hospital,

Malmö, Sweden

M. Fex $(\bowtie)$

Unit of Molecular Metabolism,

Department of Experimental Medical Science, BMC C11,

Lund University,

SE-22184 Lund, Sweden

e-mail: Malin.Fex@med.lu.se
Results HF diet resulted in insulin resistance and glucose intolerance but not frank diabetes. Basal insulin secretion was elevated in isolated islets from HF mice with almost no additional response provoked by high glucose. In contrast, a strong secretory response was seen when islets from HF mice were stimulated with fuels that require mitochondrial metabolism, such as glutamate, glutamine, alpha-ketoisocaproic acid and succinate. Moreover, while glucose oxidation was impaired in islets from HF mice, oxidation of glutamine and palmitate was enhanced. Ultrastructural analysis of islets in HF mice revealed an accumulation of lipid droplets in beta cells and a twofold increase in mitochondrial area.

Conclusions/interpretation We propose that beta cells exposed to increased lipid flux in insulin resistance respond by increasing mitochondrial volume. This expansion is associated with enhanced mitochondrial metabolism as a means of beta cell compensation.

Keywords High-fat diet - Insulin resistance . Mitochondrial metabolism Type 2 diabetes

\begin{tabular}{ll}
\multicolumn{2}{l}{ Abbreviations } \\
alpha-KIC & alpha-ketoisocaproic acid \\
BCH & 2-amino-2-norbornanecarboxylic acid \\
DMG & dimethylglutamate \\
HBSS & HEPES balanced salt solution \\
HF & High-fat diet
\end{tabular}

\section{Introduction}

Insulin resistance is a hallmark of type 2 diabetes and is frequently observed in obesity and in individuals with a sedentary lifestyle. It is usually accompanied by an adaptive 
increase in insulin secretion from pancreatic beta cells maintaining euglycaemia. However, in certain individuals, perhaps genetically predisposed, it may not be possible to fully compensate insulin resistance in the long run. This secretory deficiency consequently results in type 2 diabetes [1].

While insulin resistance as a phenomenon is incompletely understood, and the precise mechanisms at the cellular levels are yet to be fully elucidated, even less is known about beta cell compensation to insulin resistance. Several different mechanisms have been proposed to serve as signals for the beta cell to adapt to insulin resistance. A body of work implies that an elevated level of glucose during the development of insulin resistance is a signal in itself to the beta cell to increase insulin secretion [2]. Others propose that obesity and its attendant elevation of NEFAs are responsible for the development of whole-body insulin resistance [3]. The accompanying hypersecretion of insulin, with which the beta cells respond in order to maintain euglycaemia, may be caused by a lipid-derived intracellular signal [4]. Yet another line of investigation proposes that islet compensation to insulin resistance involves increased sensitivity to cholinergic stimulation [5]. Clearly, beta cell compensation is of the utmost importance, because a great number of insulin-resistant individuals would not develop frank diabetes if the compensatory mechanisms were to be maintained. Such mechanisms can be examined in females of the $\mathrm{C} 57 \mathrm{BL} / 6 \mathrm{~J}$ mouse strain, which rapidly become insulin-resistant when fed a high-fat (HF) diet, but do not develop frank diabetes [6].

The importance of mitochondrial metabolism in insulin secretion has been apparent for some time [7]. Many glycolytic and mitochondrial intermediates as well as some amino acids can readily stimulate insulin secretion [8]. They may act as or generate signalling molecules in an intracellular cascade; with ATP, the main coupling factor in insulin secretion, they work in concert to trigger and maintain a full insulin secretory response [9-12]. In fact, it was recently demonstrated that the impaired secretory response to glucose in type 2 diabetes patients was associated with both functional and morphological alterations of beta cell mitochondria [13].

In view of this, we set out to investigate the involvement of mitochondrial metabolism in the adaptive process in islets compensating for insulin resistance in order to maintain euglycaemia. For this purpose, we employed female C57BL/6J mice given an HF diet for 12 weeks.

\section{Materials and methods}

Reagents and animals All reagents were from Sigma (St Louis, MO, USA) unless otherwise stated. Female C57BL/6J mice were purchased from Taconic (Skensved, Denmark) at the age of 4 weeks. C57BL/6J mice originate from the NIH Animal Genetic Resource. In 1991 they were transferred by Caesarean into the Taconic facility and have been inbred since (http://www. taconic.com/anmodels/B6.htm). Mice were kept on an HF diet $(20 \%$ energy as protein, $20 \%$ of energy as carbohydrate and 60\% fat; Research Diets, New Brunswick, NJ, USA) or a control diet ( $20 \%$ of energy as protein, $70 \%$ as carbohydrate and $10 \%$ as fat) for 12 weeks. The studies were approved by the Regional Animal Ethics Committee in Lund.

Blood sampling Blood was collected in anaesthetised mice (midazolam; 0.4 mg per mouse; Dormicum, Hoffman-La Roche, Basel, Switzerland) and a combination of fluanison (0.9 $\mathrm{mg} /$ mouse) and fentanyl $(0.02 \mathrm{mg} /$ mouse; Janssen, Beerse, Belgium) by retro-orbital sampling. Glucose and insulin levels were determined in plasma by Glucose Trinder Assay (Sigma Diagnostics, Sigma Aldrich, Dorset, UK) and an RIA (Linco Research, St Charles, MO, USA), respectively.

IVGTTS For IVGTTs, D-glucose $(1 \mathrm{~g} / \mathrm{kg})$ was injected into the tail vein of anaesthetised mice (see above). Blood was collected at $0,1,5,20,50$ and 75 min after glucose injection for determination of plasma glucose and insulin levels as described above.

Isolation and batch incubation of islets Islets were isolated by collagenase digestion, and handpicked under a stereomicroscope. Batches $(n=8)$ of three islets for each condition were kept in HEPES balanced salt solution (HBSS; $114 \mathrm{mmol} / \mathrm{l} \mathrm{NaCl}, 4.7 \mathrm{mmol} \mathrm{KCl}, 1.2 \mathrm{mmol} / 1 \mathrm{KH}_{2} \mathrm{PO}_{4}$, $1.16 \mathrm{mmol} / 1 \mathrm{MgSO}_{4}, 20 \mathrm{mmol} / \mathrm{l} \mathrm{HEPES}, 2.5 \mathrm{mmol} / \mathrm{C} \mathrm{CaCl}_{2}$, $25.5 \mathrm{mmol} / 1 \mathrm{NaHCO}_{3}, 0.2 \% \mathrm{BSA} ; \mathrm{pH}$ 7.2) containing $3 \mathrm{mmol} / 1$ glucose for $60 \mathrm{~min}$ in an incubator at $37^{\circ} \mathrm{C}$. Three islets were transferred to a 96-well plate kept on ice and containing $200 \mu \mathrm{l}$ per well of the same buffer but with the addition of the respective secretagogue. Following transfer of all islets, the plate was placed in an incubator at $37^{\circ} \mathrm{C}$. At $60 \mathrm{~min}$, a sample from the buffer was removed for measurement of insulin by RIA (Linco Research).

Fuel oxidation After isolation, islets were kept in HBSS containing $2.8 \mathrm{mmol} / \mathrm{l}$ glucose for $60 \mathrm{~min}$ at $37^{\circ} \mathrm{C}$. Batches of islets $(n=20)$ were transferred to a cup (Kimble-Kontes, Vineland, NJ, USA) suspended from a rubber sleeve stopper (Fisher, Pittsburgh, PA, USA), which was inserted into a glass scintillation vial. For glucose oxidation, a reaction mixture containing $13 \mathrm{kBq}$ D-[U- $\left.{ }^{14} \mathrm{C}\right]$ glucose (NEN, Life Sciences, Boston, MA, USA) was added at 2.8 and $16.7 \mathrm{mmol} / 1$ glucose and the reaction was terminated after $1 \mathrm{~h}$ by injection of $100 \mu \mathrm{l} 7 \%$ perchloric acid into the suspended cup. For glutamine oxidation, the incubation 
medium contained $3.7 \mathrm{kBq} \quad$ L-[U- $\left.{ }^{14} \mathrm{C}\right]$ glutamine (NEN) mixed with $10 \mathrm{mmol} / 1$ glutamine and $10 \mathrm{mmol} / \mathrm{l}$ 2-amino2-norbornanecarboxylic acid (BCH). $\mathrm{BCH}$ was prepared as a $10 \mathrm{~mol} / 1$ stock solution and diluted 1:1,000 in HBSS to achieve the $10 \mathrm{mmol} / \mathrm{l}$ concentration used in all experiments. Oxidation of palmitate was determined over $2 \mathrm{~h}$ in a reaction mixture consisting of $0.5 \mathrm{mmol} / \mathrm{l}$ palmitic acid complexed to $1 \%$ BSA (essentially fatty acid free), with approximately $9.2 \mathrm{kBq}\left[1-{ }^{14} \mathrm{C}\right]$ palmitic acid (NEN) as tracer, and $0.8 \mathrm{mmol} / 1$ L-carnitine; glucose was added at a final concentration of 2.8 or $16.7 \mathrm{mmol} / \mathrm{l}$. The oxidation rate of $\mathrm{D}-\left[\mathrm{U}-{ }^{14} \mathrm{C}\right]$ glucose, $\mathrm{L}-\left[\mathrm{U}-{ }^{14} \mathrm{C}\right]$ glutamine, or $\left[1-{ }^{14} \mathrm{C}\right]$ palmitic acid was measured as released ${ }^{14} \mathrm{CO}_{2}$ trapped by adding $300 \mu$ l benzethonium hydroxide to the bottom of the sealed vials, followed by an additional incubation overnight at room temperature. After discarding the cups and rubber stoppers, trapped ${ }^{14} \mathrm{CO}_{2}$ was determined by scintillation counting.

Oil Red O staining of pancreatic sections A 3.7\% formaldehyde solution was made by diluting the $37 \%$ stock solution (Merck, Darmstadt, Germany) with deionised water. A stock solution of Oil Red O (Fluka Chemie, Buchs, Switzerland) was prepared by adding $500 \mathrm{mg}$ Oil Red $\mathrm{O}$ to $100 \mathrm{ml} 60 \%$ triethylphosphate $\left[\left(\mathrm{C}_{2} \mathrm{H}_{5} 0\right)_{3} \mathrm{PO}\right.$; Fluka Chemie]. Before staining, a 36\% triethylphosphate working solution was filtered through Whatman paper number 42 (Whatman, Maidstone, UK) to remove crystallised Oil Red O. Sections $(10 \mu \mathrm{m})$ from frozen tissue blocks were cut in a cryostat, thawed and air-dried, and fixed for $1 \mathrm{~h}$ in $3.7 \%$ formaldehyde, followed by thorough rinsing. Then, sections were immersed in Oil Red $\mathrm{O}$ for $30 \mathrm{~min}$, followed by three washes in deionised water (30 s). Finally, sections were rinsed with running tap water for $10 \mathrm{~min}$ and mounted with a cover slip, using $10 \%$ glycerol in PBS [14].

Immunocytochemistry Immunocytochemistry for the glucose transporter 2 (GLUT2) and insulin was performed by indirect immunofluorescence. The antibodies and procedure used have previously been described in detail [15].

Electron microscopy Islets were isolated from three HF mice and three controls. Fifty islets from each animal were pooled for two different preparations. Specimens were fixed overnight in $0.075 \mathrm{~mol} / 1$ phosphate buffer containing $3 \%$ paraformaldehyde and $1 \%$ glutaraldehyde and rinsed three times for $5 \mathrm{~min}$ in the same buffer; the specimens were post-fixed for $1 \mathrm{~h}$ with $1 \% \mathrm{OsO}_{4}$ in $0.075 \mathrm{~mol} / \mathrm{l}$ phosphate buffer, dehydrated in acetone, and embedded in Epon. Ultrathin sections were cut and placed on copper grids. All grids were contrasted with $0.5 \%$ lead citrate and $4 \%$ uranyl acetate before examination in a Philips CM10 transmission electron microscope. The mitochondrial area was measured in digitised images of ten randomly chosen beta cells; data are expressed as fractional mitochondrial area/beta cell.

Statistical methods Means \pm SEM are given. Data were compared with a two-tailed Student's $t$ test unless stated otherwise. $p<0.05$ was considered significant.

\section{Results}

Body weight, plasma glucose and insulin To study the mechanisms of insulin resistance in vivo and in vitro, C57BL/6J mice were kept on an HF diet for 12 weeks. At 10 weeks, HF mice weighed $26.2 \pm 1.1 \mathrm{~g}$ compared with control mice, which weighed $21.4 \pm 0.4 \mathrm{~g}$ (Electronic supplementary material [ESM] Fig. 1a). Analysis of metabolic changes revealed that plasma glucose levels were not significantly elevated during the whole 10 -week period (ESM Fig. 1b). In contrast, plasma insulin levels were dramatically increased already after 5 weeks on HF diet, and continued to rise during the remaining 5 weeks of the study (ESM Fig. 1c). Thus, the elevated plasma insulin levels without overt hyperglycaemia indicated compensated insulin resistance in HF mice.

IVGTTS After 10 weeks on a HF diet, an IVGTT demonstrated that glucose clearance was significantly retarded in HF mice (ESM Fig. 2a,b). Moreover, basal hyperinsulinaemia was observed, and the total amount of insulin secreted during the IVGTT was increased in HF mice (ESM Fig. 2c,d). Together, these findings confirmed insulin resistance and glucose intolerance in $\mathrm{C} 57 \mathrm{BL} / 6 \mathrm{~J}$ mice receiving $\mathrm{HF}$ diet, thus setting the stage for our studies of the cellular and molecular events underlying the adaptation of beta cells to insulin resistance.

Insulin secretion in vitro In islets from control mice, insulin secretion rose robustly when glucose was raised from 3 to $15 \mathrm{mmol} / 1$ glucose $\left(69 \pm 3\right.$ to $316 \pm 31 \mathrm{pg} \cdot$ islet $^{-1} \cdot \mathrm{h}^{-1}$; Fig. 1$)$. In islets from HF mice, basal secretion was significantly elevated at $3 \mathrm{mmol} / 1$ glucose $\left(216 \pm 37 \mathrm{pg} \cdot\right.$ islet $^{-1} \cdot \mathrm{h}^{-1}$; $p<0.01$; Fig. 1) with only a minimal additional increase to $15 \mathrm{mmol} / 1$ glucose $\left(359 \pm 53 \mathrm{pg} \cdot\right.$ islet $^{-1} \cdot \mathrm{h}^{-1}$; Fig. 1). Under $\mathrm{K}_{\mathrm{ATP}}$-independent conditions $(35 \mathrm{mmol} / \mathrm{K} \mathrm{KCl}$ and $250 \mu \mathrm{mol} / \mathrm{l}$ diazoxide), insulin secretion from $\mathrm{HF}$ islets was increased well above the levels of insulin released from control islets at $3 \mathrm{mmol} / 1\left(935 \pm 60 \mathrm{vs} 293 \pm 30 \mathrm{pg} \cdot\right.$ islet $^{-1} \cdot \mathrm{h}^{-1}$; $p=0.0004$; Fig. 1). Similar to $\mathrm{K}_{\mathrm{ATP}}$-dependent conditions, there was no additional response in islets from HF mice to an elevation in glucose concentration to $15 \mathrm{mmol} / \mathrm{l}$ (Fig. 1). Thus, islets from HF mice appeared to be sensitised under $\mathrm{K}_{\mathrm{ATP}}$-independent conditions, where metabolites from 


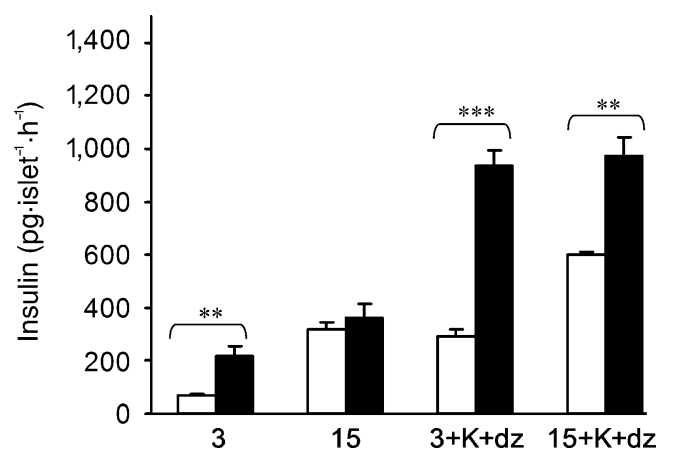

Fig. 1 Insulin secretion in vitro under $\mathrm{K}_{\mathrm{ATP}}$-dependent and -independent conditions. Isolated islets were stimulated with 3 and $15 \mathrm{mmol} / \mathrm{l}$ glucose during 1 -h static incubations. Under both $\mathrm{K}_{\text {ATP- }}$ dependent and -independent conditions $(250 \mu \mathrm{mol} / \mathrm{l}$ diazoxide $[d z]$ and $35 \mathrm{mmol} / \mathrm{K} \mathrm{KCl}[K])$, basal secretion was significantly elevated in $\mathrm{HF}$ islets vs control islets. Under $\mathrm{K}_{\mathrm{ATP}}$-independent conditions insulin secretion was significantly higher in HF islets at both basal and stimulatory concentrations of glucose. White bars, control mice; black bars, HF mice. Means \pm SEM for four independent experiments. ${ }^{* *} p<0.01 ; * * * p<0.001$

mitochondria, other than ATP, have been suggested to play an important role $[16,17]$.

Stimulation of islets in vitro with palmitate The fact that acute exposure of islets to NEFA stimulates insulin secretion has been known for some time [18]. We therefore stimulated islets from $\mathrm{HF}$ animals with $1 \mathrm{mmol} / \mathrm{l}$ palmitate. No difference in insulin secretion in islets from HF and control mice was seen at $3 \mathrm{mmol} / \mathrm{l}$ glucose in the presence of $1 \mathrm{mmol} / \mathrm{l}$ palmitate (Fig. 2a). However, at $15 \mathrm{mmol} / \mathrm{l}$ glucose, the addition of the lipid provoked a 1.7 -fold greater secretory response in HF islets compared with controls $(p=0.006)$.

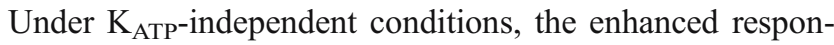
siveness to palmitate with respect to insulin secretion in $\mathrm{HF}$ islets was even more pronounced. At $3 \mathrm{mmol} / \mathrm{l}$ glucose with addition of $1 \mathrm{mmol} / \mathrm{l}$ palmitate, insulin secretion was $614 \pm$ 136 and $1,734 \pm 387 \mathrm{pg} \cdot$ islet $^{-1} \cdot \mathrm{h}^{-1}$ in control and HF islets, respectively $(p<0.0001)$. At $15 \mathrm{mmol} / 1$ glucose and $1 \mathrm{mmol} / \mathrm{l}$ palmitate, the enhancement of insulin secretion in HF islets was maintained, although the difference was not as great as at $3 \mathrm{mmol} / \mathrm{l}$ glucose ( $p=0.005$; Fig. $2 \mathrm{~b}$ ).

\section{Stimulation of islets in vitro with $\mathrm{BCH}$ or dimethylglutamate} (DMG) To determine whether HF islets were more sensitive to mitochondrial fuels, we stimulated islets with $\mathrm{BCH}$ (a nonmetabolisable form of leucine known to allosterically activate the enzyme glutamate dehydrogenase) or DMG, the cellpermeable prodrug of the amino acid. While $10 \mathrm{mmol} / \mathrm{l} \mathrm{BCH}$ elicited no increase in insulin secretion from control islets, the combination of $3 \mathrm{mmol} / \mathrm{l}$ glucose and $\mathrm{BCH}$ provoked an exaggerated secretory response in islets from HF mice (Fig. 3a). The addition of $10 \mathrm{mmol} / 1 \mathrm{DMG}$ significantly enhanced the insulin response in islets from HF mice at
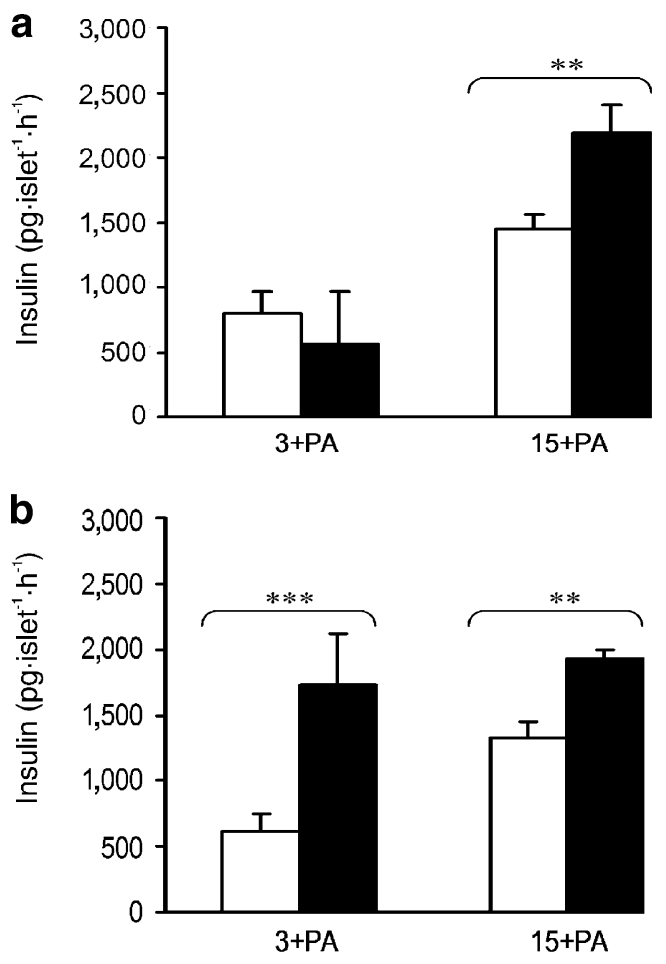

Fig. 2 Insulin secretion in vitro in response to palmitate. Isolated islets from $\mathrm{HF}$ and control mice were stimulated with 3 and $15 \mathrm{mmol} / \mathrm{l}$ glucose together with $1 \mathrm{mmol} / 1$ palmitate $(P A)$ during $1 \mathrm{~h} \mathrm{(a).} \mathrm{At}$ $3 \mathrm{mmol} / \mathrm{l}$ glucose no significant difference was detected in insulin secretion; at $15 \mathrm{mmol} / \mathrm{l}$ glucose and $1 \mathrm{mmol} / \mathrm{l}$ palmitate, insulin secretion was significantly elevated in HF islets vs control islets. Under $\mathrm{K}_{\mathrm{ATP}}$-independent conditions (b) insulin secretion in $\mathrm{HF}$ islets was greater at both 3 and $15 \mathrm{mmol} / \mathrm{l}$ glucose. White bars, control mice; black bars, HF mice. Means \pm SEM for four independent experiments. ${ }^{* *} p<0.01 ; * * * p<0.001$

$15 \mathrm{mmol} / \mathrm{l}$ glucose (Fig. 3a). In control mice, $10 \mathrm{mmol} / \mathrm{l}$ DMG at $15 \mathrm{mmol} / \mathrm{l}$ glucose also provoked an increase in insulin secretion but this response was only half of that in HF islets. Under $\mathrm{K}_{\mathrm{ATP}}$-independent conditions, using the same secretagogues (Fig. 3b), there was a strong trend, albeit not statistically significant, towards an increase in insulin secretion from HF islets.

Stimulation of islets in vitro with glutamine and $B C H$ Glutamine is known to stimulate insulin secretion in the presence of leucine or $\mathrm{BCH}$. At $3 \mathrm{mmol} / \mathrm{l}$ glucose, the addition of $10 \mathrm{mmol} / \mathrm{l}$ glutamine did not enhance secretion in islets from either HF or control mice. However, after the addition of $10 \mathrm{mmol} / \mathrm{l} \mathrm{BCH}$ to the islets, glutamine was a much more potent secretagogue in HF islets (Fig. 4a). Remarkably, under $\mathrm{K}_{\mathrm{ATP}}$-independent conditions, islets from $\mathrm{HF}$ mice responded vigorously to the addition of glutamine alone at $3 \mathrm{mmol} / \mathrm{l}$ glucose (Fig. $4 \mathrm{~b}$ ).

Stimulation of islets in vitro with alpha-ketoisocaproic acid (alpha-KIC) or methylsuccinate Alpha-ketoisocaproic acid 

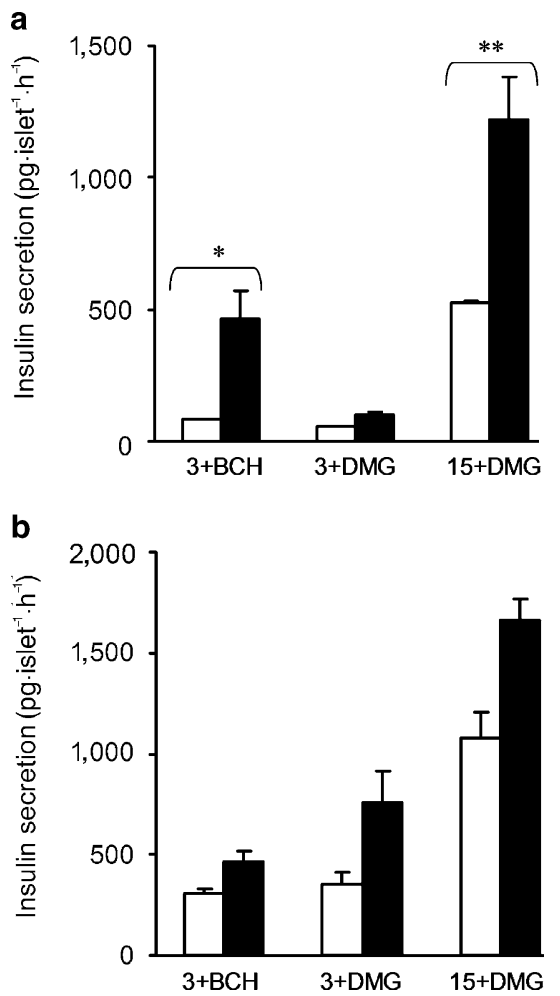

Fig. 3 Insulin secretion in vitro in response to $\mathrm{BCH}$ and DMG. Isolated islets from $\mathrm{HF}$ and control mice were stimulated with $10 \mathrm{mmol} / \mathrm{l} \mathrm{BCH}$ and $10 \mathrm{mmol} / 1 \mathrm{DMG}$ at 3 and $15 \mathrm{mmol} / 1$ glucose (a). Insulin secretion from $\mathrm{HF}$ islets was significantly greater than from control islets when stimulated by BCH. Similarly, stimulation with DMG at $15 \mathrm{mmol} / \mathrm{l}$ glucose elicited a more pronounced elevation of the secretory response in HF islets. While a similar trend was observed under $\mathrm{K}_{\mathrm{ATP}}$-independent conditions, no significant differences in insulin secretion were found (b). White bars, control mice; black bars, HF mice. Means $\pm \mathrm{SEM}$ for three independent experiments. ${ }^{*} p<0.05$; $* * p<0.01$

(alpha-KIC) is both oxidised within the mitochondria and converted to leucine through a transamination reaction with glutamate [19]. In the mitochondrion, leucine acts as an allosteric activator of glutamate dehydrogenase. Thus, employing alpha-KIC reflects various aspects of how mitochondrial metabolism controls insulin secretion. In static incubations of islets with a basal concentration of glucose $(3 \mathrm{mmol} / \mathrm{l})$ and $10 \mathrm{mmol} / \mathrm{l}$ alpha-KIC, the potentiation of insulin secretion was threefold greater in islets from HF mice than in control mice (Fig. 5). Furthermore, $10 \mathrm{mmol} / \mathrm{l}$ of the monomethyl ester of succinate (methylsuccinate), a secretagogue that may stimulate insulin secretion via flux through the anaplerotic pathway involving malic enzyme or direct activation of complex II (succinate dehydrogenase) in the respiratory chain [20], had no stimulatory effect on insulin secretion in control islets (Fig. 5), confirming previous observations in mouse islets [20]. In contrast, the addition of methylsuccinate to islets from $\mathrm{HF}$ mice revealed a dramatic increase in insulin secretion. In sum, the in vitro secretion experiments showed that HF
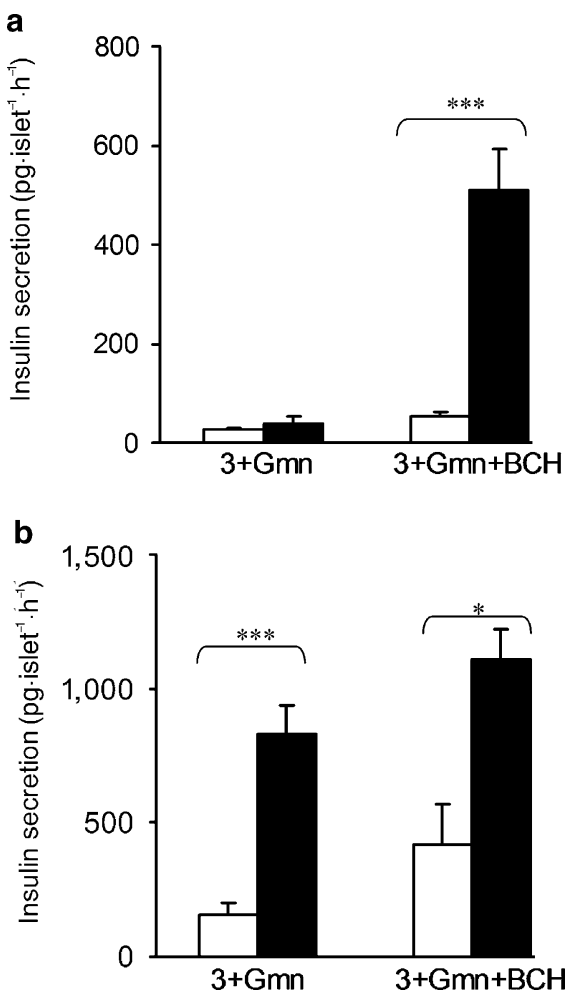

Fig. 4 Insulin secretion in vitro in response to $\mathrm{BCH}$ and glutamine. Isolated islets from $\mathrm{HF}$ and control animals were stimulated with $10 \mathrm{mmol} / 1$ glutamine (Gmn), $10 \mathrm{mmol} / \mathrm{l} \mathrm{BCH}$ and $3 \mathrm{mmol} / \mathrm{l}$ glucose (a). Glutamine alone was unable to stimulate insulin secretion in islets; however, in the presence of $\mathrm{BCH}$, a significant increase was detected in $\mathrm{HF}$ islets. Under $\mathrm{K}_{\mathrm{ATP}}$-independent conditions, glutamine alone caused a rise in insulin secretion in islets from HF animals (b). Increased insulin secretion from $\mathrm{HF}$ islets persisted when $\mathrm{BCH}$ was added. White bars, control mice; black bars, HF mice. Means \pm SEM for three independent experiments. ${ }^{*} p<0.05 ; * * * p<0.001$

islets exhibit an exaggerated secretory response when mitochondrial fuels were employed. This situation was most pronounced under $\mathrm{K}_{\mathrm{ATP}}$-independent conditions, where metabolic signals from mitochondria, in addition to ATP, are important.

In vitro fuel oxidation While the precise mechanism of the potentiation of insulin secretion by NEFA is unresolved, a common feature of the secretagogues enhancing insulin secretion from islets in HF mice in our experiments is that they are subject to mitochondrial metabolism. Therefore, we next compared fuel oxidation in HF and control islets. As expected, control islets increased the rate of glucose oxidation in response to a rise in glucose from 2.8 to $16.7 \mathrm{mmol} / 1$. In contrast, glucose oxidation in islets from HF mice was severely impaired (Fig. 6a). Next, we assessed oxidation of exogenously added palmitate in vitro. At $2.8 \mathrm{mmol} / 1$ glucose, oxidation of palmitate was significantly increased in islets from HF mice. Interestingly, palmitate oxidation in HF islets was still regulated by other metabolic events, since 


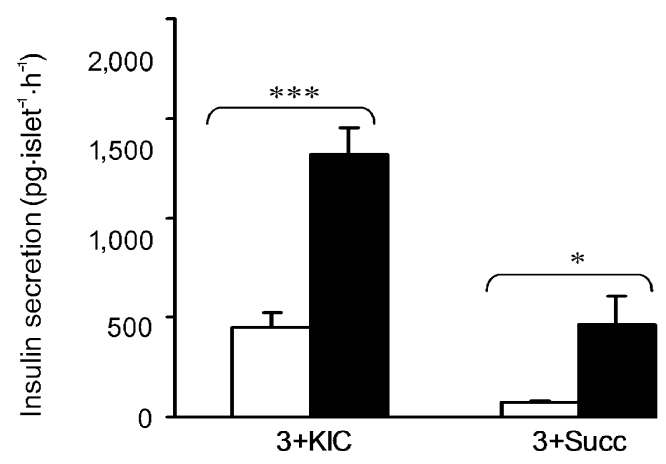

Fig. 5 Insulin secretion in vitro in response to alpha-KIC (KIC) and methylsuccinate $(\mathrm{Succ})$. Isolated islets from HF and control animals were stimulated with alpha-KIC and methylsuccinate at basal concentrations of glucose. Alpha-KIC elicited a greater secretory response in islets from HF animals as compared with controls. Similarly, stimulation with methylsuccinate also caused a significantly enhanced increase in insulin secretion from HF islets. White bars, control mice; black bars, HF mice. Means \pm SEM for three independent experiments. ${ }^{*} p<0.05 ; * * * p<0.001$

oxidation was similarly attenuated in islets from both HF animals and control animals upon an elevation of glucose concentration from 2.8 to $16.7 \mathrm{mmol} / \mathrm{l}$, presumably via generation of malonyl-CoA and inhibition of carnitine palmitoyl transferase 1 [4] (Fig. 6b). Oxidation of glutamine was threefold higher in islets from HF mice compared with controls when $\mathrm{BCH}$ was present (Fig. 6c). Thus, HF islets oxidised fuels other than glucose at an accelerated rate, suggesting enhanced mitochondrial metabolism.

Morphological analysis of islets and beta cells First, given the impaired oxidation of glucose but not of mitochondrial fuels, we examined the cellular localisation of GLUT2. The beta cell transporter of glucose is normally inserted into the plasma membrane, but this localisation has previously been reported to be disrupted when beta cell function is impaired $[21,22]$. In control islets, we observed the typical GLUT2 immunostaining of the plasma membrane in beta cells (Fig. 7a,c). In contrast, many beta cells in islets from HF mice lacked GLUT2 immunofluorescence or displayed diffuse staining. This suggests that the transporter has been lost or dislocated to the cytoplasm, where it may be of little use in glucose uptake (Fig. 7d,e).

To examine whether the presumed increased flux of NEFA in the HF mice resulted in deposition of lipids in the islets, we stained pancreatic sections with Oil Red O, which has an affinity for neutral lipid. Islets from control islets were virtually devoid of the typical red staining, while islets from HF mice displayed a diffuse red colour (Fig. 8a,b). The diameter of most lipid droplets in beta cells is below the resolution of the light microscope, and therefore ultrathin sections were prepared for electron microscopy. Beta cells from HF mice displayed numerous droplet-like structures, while such structures were absent from beta cells of the
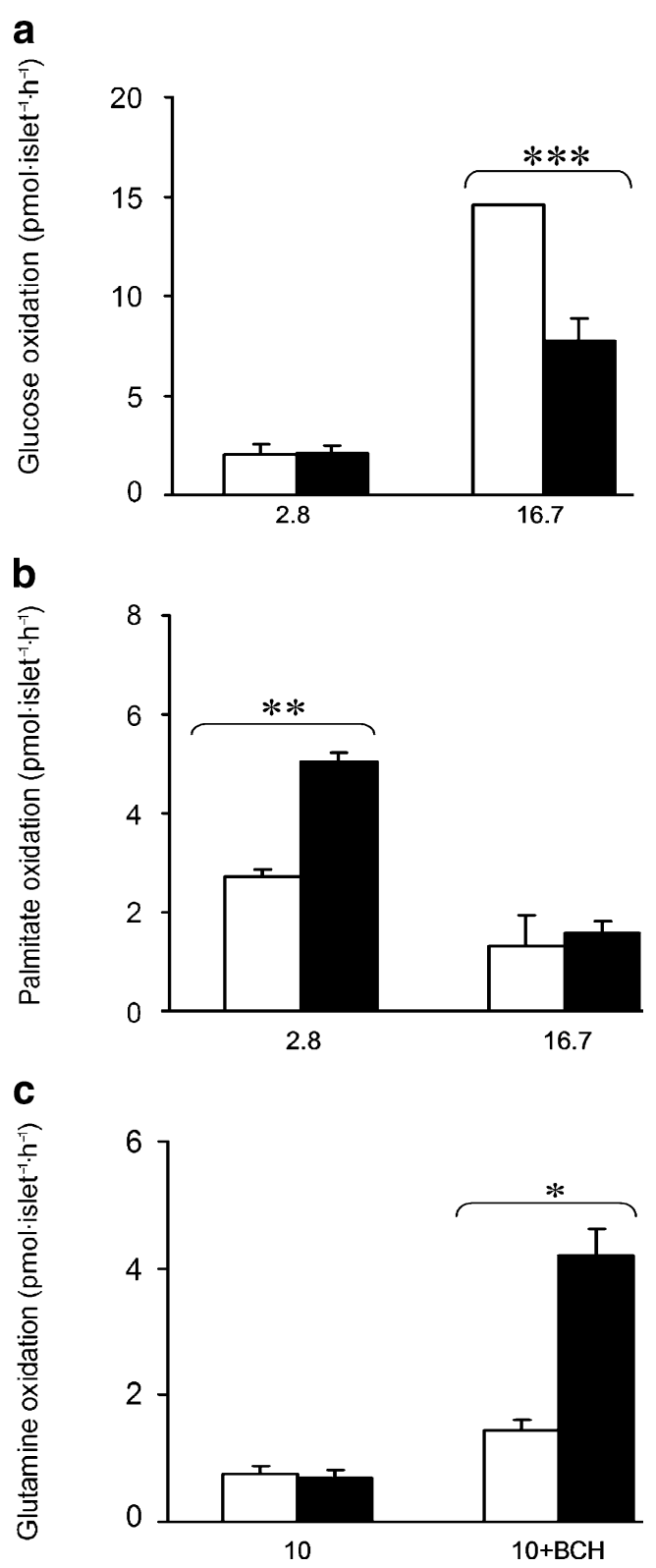

Fig. 6 Fuel oxidation in isolated islets. Glucose oxidation $(1 \mathrm{~h})$ in isolated islets from HF mice was impaired compared with that in control islets (a). Palmitate oxidation was enhanced at $2.8 \mathrm{mmol} / \mathrm{l}$ glucose in islets from HF animals (b). Glutamine oxidation in the presence of $\mathrm{BCH}$ was greatly enhanced in $\mathrm{HF}$ islets as compared with controls (c). White bars, control mice; black bars, HF mice. Means \pm SEM for three independent experiments. ${ }^{*} p<0.05 ;{ }^{* *} p<0.01$; $* * * p<0.001$

control mice (Fig. 8c,d). Together, these observations suggest that lipid droplets indeed form in beta cells from HF mice.

In view of our findings of enhanced beta cell mitochondrial metabolism and fuel-induced insulin secretion, we considered the possibility that changes in mitochondria had occurred. Using electron microscopy of islets from HF and control mice (Fig. 8c,d), we found that the mean number of mitochondria/beta cell was not significantly different between the two diets (16.7 in HF beta cells vs 16.9 in 

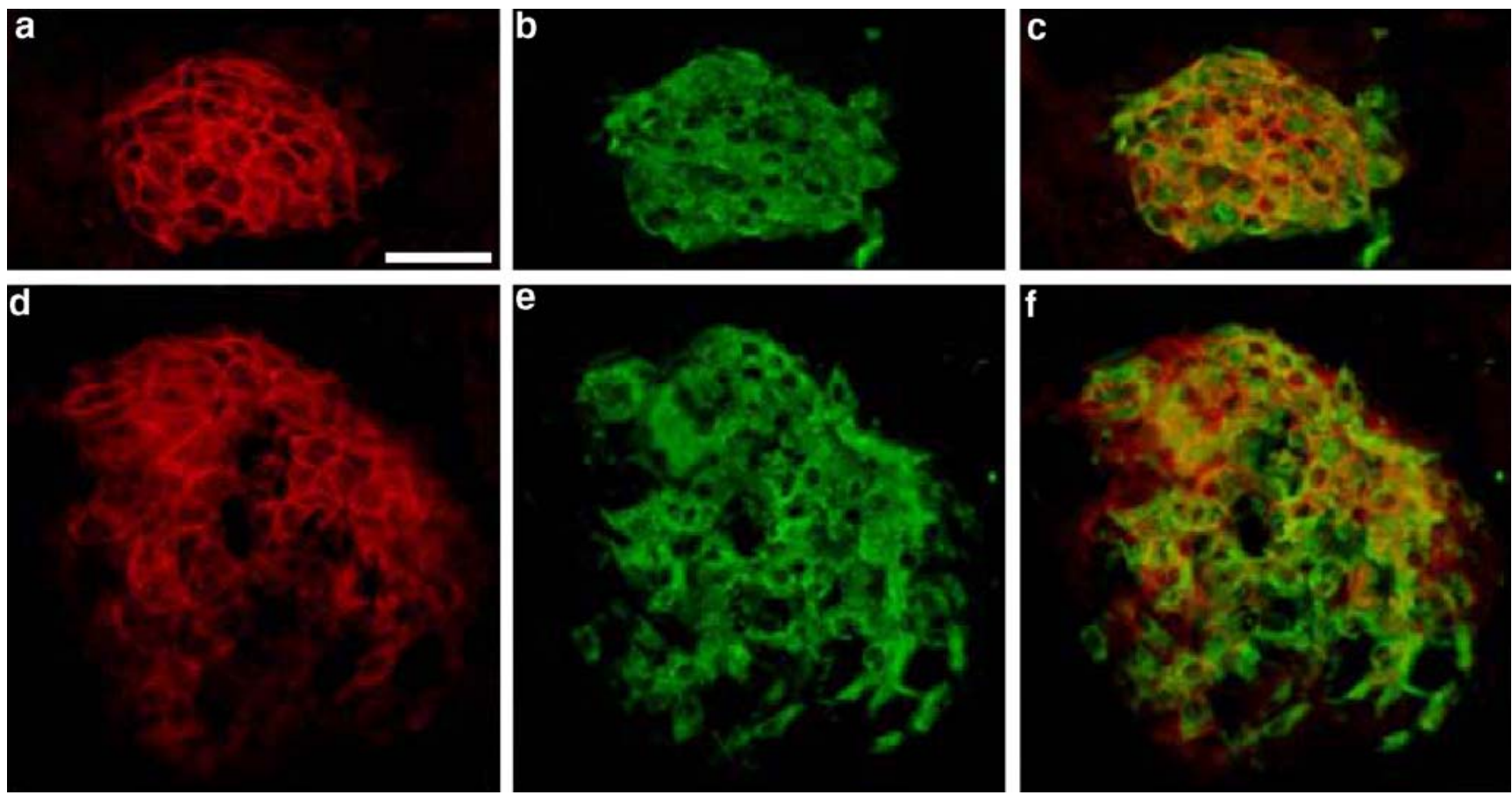

Fig. 7 Immunocytochemistry for GLUT2 and insulin. GLUT2 (a, d) and insulin immunofluorescence (green) (b, e) have been merged in control beta cells (c) and HF diet islets (f). While virtually all beta cells harbour GLUT2 immunofluorescence in control islets (a, c),

controls; $n=10$ beta cells for each diet). However, when calculating mean mitochondrial area/beta cell, we found that it was increased $~$ twofold in beta cells from HF mice compared with control animals $(9.4 \pm 1.7 \%$ in HF beta cells vs $5.7 \pm 3.2 \%$ in control beta cells; $p<0.01$; Fig. 9).

\section{Discussion}

Mitochondrial metabolism is crucial for all cells. In beta cells, mitochondrial metabolism largely controls insulin secretion. An important role for beta cell mitochondria, besides generation of ATP, the coupling signal which triggers insulin secretion, is to generate additional coupling factors that sustain secretion. Thus, a number of metabolic intermediates from the tricarboxylic acid cycle may couple beta cell metabolism to exocytosis [7, 9, 10]. If these processes fail, insulin secretion will be perturbed. This is a hallmark of type 2 diabetes. In fact, it was recently shown that mitochondrial function and structure are altered in human pancreatic islets from type 2 diabetes subjects in parallel with impaired fuel-stimulated insulin secretion [13]. While no definitive information has established the cause of mitochondrial dysfunction in type 2 diabetes, it has been suggested that elevated levels of circulating NEFA may play an important role. Hence, increased intracellular stores of triacylglycerol in non-adipose tissues may arise as a primarily in the plasma membrane, beta cells in HF islets are either lacking GLUT2 or the staining has become diffuse, suggesting loss of the transporter or its dislocation from the membrane (d, f). $B a r=20 \mu \mathrm{m}$

consequence of increased circulating NEFA and be involved in the development of insulin resistance [23]. Such increases have also been observed in beta cells in animal models of type 2 diabetes [24]. In insulin-resistant states, normal glucose levels are maintained by increased secretion of insulin from beta cells. These changes in compensatory insulin secretion could be mediated by alterations of mitochondrial metabolism. If compensation is exhausted, due to mitochondrial dysfunction, insulin secretion fails and type 2 diabetes will develop. Our goal here was to examine changes in beta cell mitochondrial metabolism in a model of HF-induced insulin resistance.

C57BL/6J mice were given an HF diet. Insulin resistance evolved rapidly; this was confirmed by an IVGTT after 10 weeks. In vitro insulin secretion from HF islets was perturbed, and the normal response to elevated concentrations of glucose was lost. Concurrently, glucose oxidation was markedly impaired in HF islets. Glucose metabolism is dependent on substrate availability. Consequently, if glucose uptake into the beta cell is impaired, glucose oxidation will be diminished. In fact, localisation and expression of GLUT2 in beta cells in C57BL/6J mice given an HF diet have previously been shown to be perturbed $[21,25]$. Indeed, we found a similar dislocation of GLUT2, and this is presumably responsible, to some extent, for the perturbation of glucose oxidation that we and others have observed. A study in female NMRI mice fed an HF diet for 12 weeks has also demonstrated perturbed 
Fig. 8 Oil Red O staining, and electron micrographs (EMs) of islets and beta cells from control $(\mathbf{a}, \mathbf{c})$ and HF mice $(\mathbf{b}, \mathbf{d})$. Oil Red O staining for neutral lipids in pancreatic sections from control animals (a) and HF animals (b). Control islets lack Oil Red O staining, while HF islets display a diffuse red colour, indicating the presence of lipid. EM images of control (c) and HF (d) beta cells. Cytoplasmic lipid droplets in HF beta cells are indicated by black arrows in (d), but are lacking in control beta cells (c)
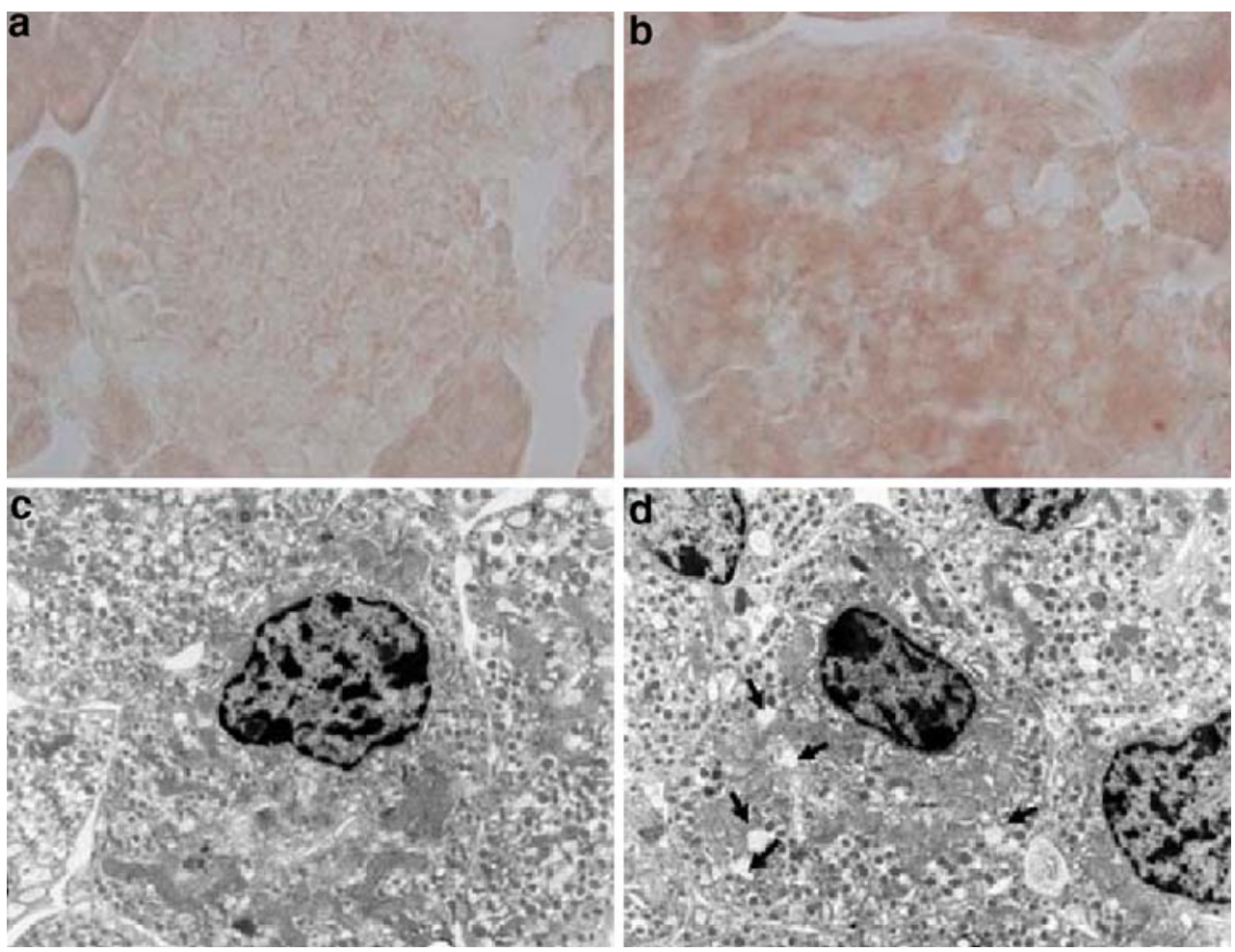

glucose oxidation [26]. Here, the metabolic perturbation was mainly attributed to a reduced activity of glucokinase, the first step in glycolysis, underscoring the critical role of this rate-limiting enzyme. In both cases it was argued that elevated levels of plasma NEFA cause the perturbations of GLUT2 translocation and glucokinase activity. While we have not yet been able to show an elevation of plasma NEFA in our model, we believe that there is an increased flux of NEFA in the HF mice. This is supported by our observations of lipid deposition as well as intracellular lipid droplets in the beta cells in HF mice. In those instances when elevated plasma NEFA was reported in this and similar models, HF diet was given for longer time periods [6]. In vitro analysis of insulin secretion in islets from our HF animals indicated a hypersensitivity to metabolic fuels other than glucose, such as DMG, glutamine, methylsuccinate, alpha-KIC and

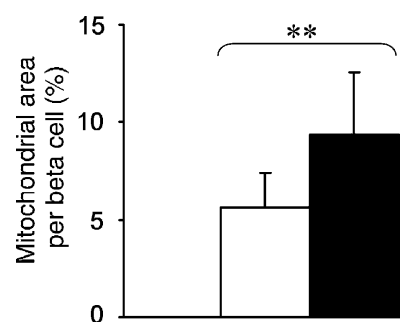

Fig. 9 Mitochondrial area in beta cells from control and HF islets. Mean mitochondrial area is significantly increased in beta cells from HF mice. White bar, control mice; black bar, HF mice. Means \pm SD from calculations performed in ten randomly chosen beta cells. $* * p<0.01$ palmitate. Moreover, we found a significant increase in oxidation of both glutamine and palmitate in islets from HF mice. This shift in metabolism from oxidation of glucose to that of mitochondrial fuels was accompanied by morphological changes in mitochondria; we found a significant increase (1.65-fold) in mitochondrial surface area. Based on this, we propose that beta cells compensate for insulin resistance by increasing mitochondrial area, thereby increasing mitochondrial metabolism, which in turn underlies the circulating hyperinsulinaemia and the exaggerated response to mitochondrial fuels. These events may very well be driven by the increased flux of NEFA that arises in the mice as a consequence of HF feeding. The fact that beta cells express G-protein-coupled receptors that utilise NEFA as ligands, the GPR 40 family [27-29], raises the possibility that receptor-mediated events triggered by lipids account, at least partially, for the mitochondrial adaptation. Whereas the physiological role of the GPR 40 receptors is still unresolved, our present findings point to an interesting area of beta cell physiology that could be examined with GPR 40 receptors in mind.

In 2005, Rabaglia et al. [30] published a study in Brattleboro (BTBR) mice, which are also prone to develop insulin resistance. In line with our observations, they reported that alpha-KIC provokes a hyperinsulinaemic response in islets from BTBR rats. Our extended studies here showed that several other amino acids and palmitate elicited a similar response in islets from insulin-resistant HF mice. In addition, we showed that the hypersecretion from 
the HF islets was combined with a morphological alteration of beta cell mitochondria.

Recent studies in a strain of $\mathrm{C} 57 \mathrm{BL} / 6 \mathrm{~J}$ mice kept in Oxford identified the nicotinamide nucleotide transhydrogenase (NNT) locus as a potential diabetes gene [31]. Knock-down of the gene in MIN-6 cells, using RNA interference, or genetic inactivation in mice, results in impaired glucose - but not sulphonylurea-induced insulin secretion [32]. Given the role of NNT in mitochondrial metabolism and the finding of impaired ATP production, the authors suggested that perturbed mitochondrial metabolism accounts for the secretory deficiency in their strain of C $57 \mathrm{BL} / 6 \mathrm{~J}$ mice. Whether our colony of $\mathrm{C} 57 \mathrm{BL} / 6 \mathrm{~J}$ mice has the same genetic defect is unresolved. In contrast to their colony, our C57BL/ $6 \mathrm{~J}$ control mice exhibit robust fuel-stimulated insulin secretion. Furthermore, even after prolonged HF diet, the mice are resistant to diabetes development [6]. Finally, in our studies, we use female mice, which are less diabetes-prone than male mice. In fact, this phenotype was the rationale for our choice of using HF diet feeding of C57BL/6J mice as a model to study beta cell adaptation to insulin resistance. This again emphasises the critical role of genetic background and/ or specific genes for diabetes development. This has become even more evident when identical genetic manipulations, i.e. gene knock-outs, have been analysed in different genetic backgrounds, in many instances yielding dissimilar results with respect to glucose homeostasis [33, 34].

In view of our results here, mitochondria and the attendant complex metabolic changes may play an important, if not decisive, role for beta cell compensation to insulin resistance. Facilitation of such compensation may enhance beta cell function and insulin secretion, and thereby prevent the development of hyperglycaemia and type 2 diabetes. Perhaps, such molecular mechanisms may prove to be a feasible target for therapeutic intervention in type 2 diabetes.

Acknowledgement We thank Ann-Helen Thorén Fischer for technical assistance with IVGTTs. These studies were supported by grants from The Swedish Research Council (14196-03A: H. Mulder), The Albert Påhlsson, Åke Wiberg, Ingrid and Fredrik Thuring Foundation, The Swedish Diabetes Association, The Krapperup Foundation (to M. Fex) and the Faculty of Medicine, Lund University.

Duality of interest There is no duality of interest for any of the authors for this study.

\section{References}

1. Reaven GM (1993) Role of insulin resistance in human disease (syndrome X): an expanded definition. Annu Rev Med 44:121-131

2. Relimpio F (2003) 'The relative contributions of insulin resistance and beta-cell dysfunction to the pathophysiology of type 2 diabetes', by Kahn SE. Diabetologia 46:1707

3. Shulman GI (2000) Cellular mechanisms of insulin resistance. $\mathrm{J}$ Clin Invest 106:171-176
4. Prentki M, Corkey BE (1996) Are the beta-cell signaling molecules malonyl-CoA and cystolic long-chain acyl-CoA implicated in multiple tissue defects of obesity and NIDDM? Diabetes $45: 273-283$

5. Ahren B, Simonsson E, Scheurink AJ, Mulder H, Myrsen U, Sundler F (1997) Dissociated insulinotropic sensitivity to glucose and carbachol in high-fat diet-induced insulin resistance in C57BL/6J mice. Metabolism 46:97-106

6. Ahren B, Scheurink AJ (1998) Marked hyperleptinemia after high-fat diet associated with severe glucose intolerance in mice. Eur J Endocrinol 139:461-467

7. Wollheim CB (2000) Beta-cell mitochondria in the regulation of insulin secretion: a new culprit in type II diabetes. Diabetologia 43:265-277

8. Malaisse WJ, Sener A, Malaisse-Legae F, Hutton JC, Christophe J (1981) The stimulus-secretion coupling of amino acid-induced insulin release. Metabolic interaction of L-glutamine and 2-ketoisocaproate in pancreatic islets. Biochim Biophys Acta 677:39-49

9. Maechler P, Wollheim CB (2001) Mitochondrial function in normal and diabetic beta-cells. Nature 414:807-812

10. Maechler P (2002) Mitochondria as the conductor of metabolic signals for insulin exocytosis in pancreatic beta-cells. Cell Mol Life Sci 59:1803-1818

11. Sener A, Malaisse WJ (1980) L-leucine and a nonmetabolized analogue activate pancreatic islet glutamate dehydrogenase. Nature 288:187-189

12. Sener A, Malaisse-Lagae F, Malaisse WJ (1981) Stimulation of pancreatic islet metabolism and insulin release by a nonmetabolizable amino acid. Proc Natl Acad Sci USA 78:5460-5464

13. Anello M, Lupi R, Spampinato D et al (2005) Functional and morphological alterations of mitochondria in pancreatic beta cells from type 2 diabetic patients. Diabetologia 48:282-289

14. Koopman R, Schaart G, Hesselink MK (2001) Optimisation of oil red $\mathrm{O}$ staining permits combination with immunofluorescence and automated quantification of lipids. Histochem Cell Biol 116:63-68

15. Mulder H, Gebre-Medhin S, Betsholtz C, Sundler F, Ahren B (2000) Islet amyloid polypeptide (amylin)-deficient mice develop a more severe form of alloxan-induced diabetes. Am J Physiol Endocrinol Metab 278:E684-E691

16. Henquin JC (2000) Triggering and amplifying pathways of regulation of insulin secretion by glucose. Diabetes 49:1751-1760

17. Wollheim CB, Maechler P (2002) Beta-cell mitochondria and insulin secretion: messenger role of nucleotides and metabolites. Diabetes 51(Suppl 1):S37-S42

18. Malaisse WJ, Malaisse-Lagae F (1968) Stimulation of insulin secretion by noncarbohydrate metabolites. J Lab Clin Med 72:438-448

19. Gao Z, Young RA, Li G et al (2003) Distinguishing features of leucine and alpha-ketoisocaproate sensing in pancreatic beta-cells. Endocrinology 144:1949-1957

20. Fahien LA, MacDonald MJ (2002) The succinate mechanism of insulin release. Diabetes 51:2669-2676

21. Reimer MK, Ahren B (2002) Altered beta-cell distribution of pdx1 and GLUT-2 after a short-term challenge with a high-fat diet in C57BL/6J mice. Diabetes 51(Suppl 1):S138-S143

22. Milburn JL Jr, Ohneda M, Johnson JH, Unger RH (1993) Betacell GLUT-2 loss and non-insulin-dependent diabetes mellitus: current status of the hypothesis. Diabetes Metab Rev 9:231-236

23. Unger RH (1995) Lipotoxicity in the pathogenesis of obesitydependent NIDDM. Genetic and clinical implications. Diabetes 44:863-870

24. Lee Y, Hirose H, Zhou YT, Esser V, McGarry JD, Unger RH (1997) Increased lipogenic capacity of the islets of obese rats: a role in the pathogenesis of NIDDM. Diabetes 46:408-413

25. Johnson JH, Ogawa A, Chen L et al (1990) Underexpression of beta cell high $K_{\mathrm{m}}$ glucose transporters in noninsulin-dependent diabetes. Science 250:546-549 
26. Capito K, Reinsmark R, Thams P (1999) Mechanism of fatinduced attenuation of glucose-induced insulin secretion from mouse pancreatic islets. Acta Diabetol 36:119-125

27. Salehi A, Flodgren E, Nilsson NE et al (2005) Free fatty acid receptor 1 (FFA(1)R/GPR40) and its involvement in fattyacid-stimulated insulin secretion. Cell Tissue Res 322: 207-215

28. Steneberg P, Rubins N, Bartoov-Shifman R, Walker MD, Edlund $\mathrm{H}$ (2005) The FFA receptor GPR40 links hyperinsulinemia, hepatic steatosis, and impaired glucose homeostasis in mouse. Cell Metab 1:245-258

29. Itoh Y, Kawamata Y, Harada M et al (2003) Free fatty acids regulate insulin secretion from pancreatic beta cells through GPR40. Nature 422:173-176

30. Rabaglia ME, Gray-Keller MP, Frey BL, Shortreed MR, Smith LM, Attie AD (2005) Alpha-ketoisocaproate-induced hypersecre- tion of insulin by islets from diabetes-susceptible mice. Am J Physiol Endocrinol Metab 289:E218-E224

31. Toye AA, Lippiat JD, Proks P et al (2005) A genetic and physiological study of impaired glucose homeostasis control in C57BL/6J mice. Diabetologia 48:675-686

32. Freeman H, Shimomura K, Horner E, Cox RD, Ashcroft FM (2006) Nicotinamide nucleotide transhydrogenase: a key role in insulin secretion. Cell Metab 3:35-45

33. Kulkarni RN, Holzenberger M, Shih DQ et al (2002) Beta-cellspecific deletion of the Igfl receptor leads to hyperinsulinemia and glucose intolerance but does not alter beta-cell mass. Nat Genet 31:111-115

34. Kulkarni RN, Bruning JC, Winnay JN, Postic C, Magnuson MA, Kahn CR (1999) Tissue-specific knockout of the insulin receptor in pancreatic beta cells creates an insulin secretory defect similar to that in type 2 diabetes. Cell 96:329-339 